УДК 784.1

DOI: 10.37026/2520-6427-2020-102-2-172-175
Оксана ДЕМ'ЯНЮК,

стариий викладач кафедри хорового диригування Інституту мистеитв

Рівненського державного гуманітарного університету

\title{
СПЕЦИФІКА РОБОТИ НАД ЕЛЕМЕНТАМИ ХОРОВОЇ ЗВУЧНОСТІ В ХОРОВОМУ КОЛЕКТИВІ
}

У статті крізь призму тлумачення низки елементів хорової звучності (ансамбль, стрій, дикиія, динаміка (нюансування), агогіка) як ключових компонентів (складових) хорового виконавства аналізується специфіка вокальної роботи в хоровому колективі. В цьому контексті неабияка увага приділяється тлумаченню співацького хорового дихання, бездоганне застосування якого створює необхідні умови для роботи над ключовими елементами хорової звучності.

Ключові слова: співацьке дихання, стрій, інтонація, ансамбль, нюансування, дикція, артикуляиійний апарат, елементи хорової звучності.

В статье анализируется специифика вокальной работы в хоровом коллективе сквозь призму толкования ичелого спектра элементов хоровой звучности, как ключевых базовых компонентов (составляющих) хорового исполнительства, без совершенного владения которыми невозможное функиионирование хора как художественного коллектива. Доказано, что качество строя, ансамбля, нюансировки, а также других элементов художественной выразительности обусловлено певческим дыханием, которое является важнейшим фактором в работе над элементами хоровой звучности. Охарактеризованы певческие недостатки, имеющиеся в практике хорового исполнительства, предложены пути их устранения.

Ключевые слова: дыхание певца, строй, интонация, ансамбль, нюансирование, дикция, артикуляциионньй аппарат, элементь хоровой звучности.

The article deals with "Specificity of work on elements of choral sonority in a choral collective» the peculiarities of vocal work in the choir are analyzed through the prism of interpretation of a number of elements of choral sonority (ensemble, structure, diction, dynamics (nuance), agogics), as key components of choral performance. In this context great attention is paid to the interpretation of singing choral breathing, the perfect application of which creates the necessary conditions for work on key elements of choral sonority.
Regarding the analysis of the latter, the author focuses on a critical assessment of a number of elements of choral sonority - ensemble singing, system, diction, dynamics (nuance) and agogics. Thus, the analysis of ensemble singing is reduced to the interpretation of this element of choral sonority to the coordinate system of a modern choral score, through the prism of peculiarities of polyphony (10-15 voices), the specificity of the individual voice-part and a kind of acoustic dissonance. Understanding the problem of the system is presented from the point of view of mastering the skills of "pure» intonation, based on the laws of structure (major, minor) and intervals, as well as the intonation style of modern choral music against the background of spreading the latest means of choral writing.

Much attention in this article is paid to another element of choral sonority-diction, which is interpreted from the point of view of a skillful combination of words and music in choral singing. At the same time, the importance of working on dynamics, agogics and nuance is pointed out. Analyzing the dynamics as one of the most important elements of choral sonority, the author proves that adherence to a motivated dynamic palette of a work performed will provide the choir with the necessary conditions to create full artistic imagery of the performed works.

The publication also points out that a very important element of choral sonority is an extremely significant musical component-agogics, regulating the admissibility, in the process of performing work, a slight deviation from the specified tempo of a composer on condition of preserving the latter as a whole. It is emphasized that the logical, in accordance with the content of the work, "construction» of dynamic-agogic pulsation of the work is the key to maximum proximity to the creation of an ideal artistic image.

In conclusion, the author asserts that the work on the elements of choral sonority in the choir is the most important because its effectiveness, under certain conditions, can provide a high performing culture of the choir, as the highest value measure of it.

Key words: breathing of singer, line-up, intonation, ensemble, nuances, diction, articulatory vehicle, elements of choral sonority. 
Постановка проблеми. Українська хорова музика як один із найбільш давніх видів національного музичного мистецтва виконує сьогодні роль музично-естетичної матриці, в межах якої, з одного боку, утримується музичний традиціоналізм, а 3 іншого - продукується нове музичне мислення, що базується на поєднанні автентики із новими техніками композиторського письма, що створює природні умови для еволюційного розвитку даного виду мистецтва.

Надважливе значення у цьому процесі відводиться хоровому виконавству як своєрідному музично-естетичному моделюванню найрізноманітніших зразків такої музики на практиці. Зауважимо, що в рамках даного виконавства в усі історичні періоди розвитку хорового мистецтва в Україні виключно важливими формами роботи були, є й надалі залишаються ті, що спрямовані на опанування хористами вокальної культури, котра насамперед зводиться до вдосконалення ключових виконавських елементів хорової звучності: хорового строю, хорового ансамблю, динаміки, дикції та ін. Тлумачення дієвості останніх у сучасних умовах розвитку хорового українського мистецтва видається нам неабияк актуальним.

Аналіз наукових досліджень і публікацій. Найрізноманітніші аспекти проблематики, пов'язаної із вокальною роботою в хоровому колективі аналізують В. Бриліант, В. Живов, О. Коломоєць, А. Лащенко, А. Мархлевський, В. Мухін, Д. Огороднов, В. Палкін, К. Пігров, Г. Стулов В. Чернушенко, П. Чесноков, Л. Шаміна та ін. На сучасному етапі проблеми, пов'язані 3 аналізом елементів хорової звучності, розглядають: Т. Смирнова (проблеми ансамблю та строю), О. Батовська (ключові аспекти строю в сучасній хоровій музиці, О. Сіненко, Л. Остапенко (проблеми ансамблевого співу в хорі), С. Данилишина, А. Тишина (проблеми строю в хорових творах) та ін.

Проте аналіз наукових праць означених вище авторів засвідчує, що намагання дослідників останніх десятиліть передусім зводяться до вирішення низки проблем, пов'язаних із культурою хорового виконавства, орієнтованого на класико-романтичну традицію хорового музикування в Україні. Щодо сучасного етапу розвитку національного хорового мистецтва, то він, безумовно, цікавий тим, що хорові полотна сучасних композиторів все більше збагачуються новітніми техніками композиторського письма (сонорика, алеаторика, серійна музика, паунтилізм, додекафонія, техніки з ознаками мінімалізму, мікрополіфонії, спектралізм нової простоти й нової складності тощо), які й зумовлюють необхідність осмислення, опанування й застосування у сфері хорового виконавства вокальних технологій сьогодення. Саме тлумачення останніх і пропонуємо окреслити у нашій розвідці.

Мета статті - окреслити основні елементи хорової звучності в хоровому колективі, а саме ансамбль, стрій, дикція, динаміка (нюансування), агогіка, в системі координат сучасного хорового виконавства.

Виклад основного матеріалу. Аналізуючи означену нами проблему, найперше варто наголосити, що запорукою вокальної культури того чи іншого хорового колективу має стати скрупульозний підхід до роботи над ключовими елементами хорової звучності, покликаної забезпечити творчі передумови високого виконавського рівня сучасного хору. У зв'язку з цим зауважимо, що якість строю, ансамблю, нюансування та інших елементів художньої виразності зумовлюється співацьким диханням, яке $€$ ключовим та найважливішим фактором у роботі над елементами хорової звучності. Для того, щоб проаналізувати специфіку формування співацького дихання у процесі роботи над елементами хорової звучності, найперше варто проаналізувати означену проблему $з$ точки зору кардинально протилежних недоліків співацького дихання, які нерідко проявляються у практиці хорового виконавства, наприклад, з одного боку, наявність недостатньо активного дихання, а з іншого - надмірно напруженого. Так, за умови застосування недостатньо активного дихання передусім понижується загальний виконавський тонус як окремого співака, так і хору в цілому. При цьому стає помітною специфіка інтонування інтервалів, як правило, висхідних, із тенденцією до пониження. За таких умов, звичайно ж, порушується стрій інтонаційних утворень мелодики, що є надзвичайно вагомим виконавським недоліком, не усунувши який, практично неможливо провадити репетиційну роботу, спрямовану на якісно-бездоганне звучання хору.

Недостатня активність співацького дихання під час співу хору зумовлюється зазвичай двома основними причинами: 1) цілковитим або ж недостатнім умінням хористів у процесі раціонального використання видиху впродовж усієї музичної фрази користуватися правильним співацьким диханням; 2) фізичною втомою співаків, спричиненою низкою факторів навколишнього середовища, як-от непровітрене приміщення репетиційної аудиторії, зниження атмосферного тиску та ін.

Не можемо не звернути нашу увагу й на кардинально протилежний недолік, який часто трапляється у виконавській хоровій практиці, - спорадичне застосування напружено-надмірного співацького дихання, яке нерідко спостерігається у процесі виконання того чи іншого твору низкою хорових колективів, спонукаючи форсування їх звучання й інтонаційну нестійкість. Саме ці негативні прояви і $€$ наслідком втрати контролю хористів над співацьким диханням під час концертних виступів унаслідок їх надмірного психологічного збудження. Для подолання вказаних виконавських недоліків радимо під час репетицій провадити систематичну роботу, спрямовану на осмислене формування й повноцінне застосування нижньореберного або ж діафрагматичного співацького дихання, зокрема враховуючи всі структурні складові, спрямовані на формування цілісного процесу співацького дихання, починаючи від теоретичного осмислення фізіологічної будови системи дихання співацького апарату хориста й закінчуючи напрацюванням навичок співу в режимі застосування нижньореберно-діафрагматичного типу дихання, в процесі якого максимально активізується робота м’язів грудної клітки, черевного пресу та діафрагми. 
Варто також звертати увагу на особливості використання правильного співацького дихання впродовж усієї музичної фрази, застосовуючи як уміння повноцінної подачі дихання у процесі формування голосних і приголосних літературно-поетичного тексту того чи іншого музичного фрагмента, так і вміло використовуючи специфіку ланцюгового дихання, яке передусім $є$ запорукою бездоганного кантиленного звучання не лише певної музичної фрази, а й загалом усього твору. Що ж стосується подолання недоліку форсованого співу, який інколи є причиною нечистоти інтонування, то радимо хормейстерам більше звертати увагу хористів на безпосередній процес створення художнього образу, адекватні рамки якого унеможливлять вдаватися до форсування або ж інших небажаних виконавських проявів [1].

Крім того, хормейстер не повинен забувати про створення належних умов для репетиційної й концертної роботи колективу, уникати найрізноманітніших несприятливих факторів, які можуть загрожувати його повноцінній, якісній репетиційно-концертній діяльності, зокрема не допускати репетицій у непровітрених аудиторіях, за наявності фізичної втоми співаків, що у будь-якому випадку не сприятиме їхній повноцінній роботі.

Співацьке дихання - це основа вокально-хорової культури. Вона базується на низці складових хорової звучності: строї, ансамблевому співі та градаційних проявах нюансування. Зважаючи на це, спробуємо проаналізувати роботу над строєм у сучасному хоровому колективі.

Уміння співати «чисто», із точки зору традиційного підходу щодо набуття навичок інтонування, основна якість хорового виконавства. Тобто, вміння бездоганного інтонування слід не просто виховувати, а й постійно удосконалювати, тренувати. В основу правильного інтонування покладено певні правила, що грунтуються на закономірностях будови ладу (мажор, мінор) та інтервалах, які обов'язково слід застосовувати у процесі роботи над інтонацією. Більше того, останнє, на нашу думку, необхідно неабияк «відточувати», передусім шляхом максимально точного підлаштовування хористів один під одного, досягаючи при цьому ідеального ансамблю, а отже, й чистої інтонації.

Проте інтонаційна стилістика сучасної хорової музики потребує застосування нових вокальних прийомів, які суттєво відрізняються від класико-романтичних. Упровадження в хорову музику новітніх засобів хорового письма, в яких спостерігається поступове послаблення ладоспрямованої ролі гармонії, посилення фонічних властивостей акордів, співзвуч, кластерів тощо, потребують значної технічної роботи в сучасному хорі. Так, на сучасному етапі розвитку музичного мистецтва дієвими є новітні методики, що сприяють напрацюванню модернових виконавських навичок, основною 3 яких - інтонування чвертьтонових звукових співвідношень [2].

Опанування сучасним хором уміння бездоганно інтонаційно відтворювати кластери та інші складні акордові співзвуччя потребують неабиякої майстерності. Для подолання складних моментів, пов'язаних
3 утримуванням «гострих» дисонансів, для розспівування хору пропонуємо добирати поспівки з відтворення гам у паралельному русі, спів гармонічних інтервалів, вправи з хроматичним інтонуванням у гармонічному оточенні, а також вправлятися в інтонаційному відтворенні паралельних рухів терціями, квартами, квінтами чи гармонізованої хроматичної гами тощо $[1 ; 3 ; 7]$.

Як відомо, сучасна хорова партитура вимагає внесення в поняття «ансамбль» деяких корективів. Так, аналізуючи роботу ансамблю, варто пам'ятати, що в багатьох партитурах сучасної хорової музики трапляється багатоголосся із 10-15-ти голосів, хоча в умовах камерного хорового виконавства, досить популярного на сьогодні, кожному співакові відведено статус індивідуального голосу-партії, своєрідної «цеглинки» в загальній гармонічній побудові твору [3, с. 74]. Також варто зауважити, що сучасні гармонії складаються 3 нетерцових конструкцій, а у поєднанні з акордами - терцових, створюючи таким чином своєрідний акустичний дисонанс. У зв'язку $з$ цим гармонія набуває специфічних тембрального й сонористичного відтінків. Ансамбль за таких умов досягається за рахунок високого професіоналізму співаків, які мають володіти якостями не лише співака-соліста, а й бездоганного ансамбліста. Ці навички необхідно напрацьовувати, використовуючи як спеціальні технічні вправи, так і окремі фрагменти художнього матеріалу. Лише за таких умов можна досягнути бажаного результату [7].

Важливе місце у роботі з хором займає ще одна складова хорової звучності - нюансування, дієвість якої передбачає виконання твору або ж окремих його частин відповідно до задуму композитора, наприклад, використовуючи найрізноманітніші динамічні відтінки, в основу яких покладено різну силу звучання. Дотримання хором художньо вмотивованої палітри нюансування, яка додаватиме значимості у створенні художнього образу твору, що виконується, - надважливе завдання творчого процесу того чи іншого хорового колективу. Тобто, недотримання чіткої та якісно виваженої послідовності сили звучання у творах, що виконуються, зумовлює появу низки недоліків у хоровому виконавстві, як-от галасливий спів, тьмяне або ж безбарвне звучання, невмотивовано дуже голосне чи навпаки - притишене звучання, які зазвичай викликають появу інтонаційних недоліків тощо.

Вдаючись до тлумачення особливостей нюансування в хорі, зазначимо, що навик співу з нюансами тісно пов'язаний зі співацьким диханням. Відповідно до цього і хормейстер, і співаки повинні розуміти, що специфіка тихого або ж дуже тихого співу (спів на $p$, чи то на $p p$ ) має базуватися на дуже активному співацькому нижньореберному чи діафрагматичному диханні. Такий спів вимагає від хориста надзвичайно активного дихання і виразної вимови літературно-поетичного тексту. Отже, вміння хору співати, використовуючи різні нюанси - від рianissimо (дуже тихо) до fortissimo (дуже голосно), без порушень інших виконавських якостей (чистоти інтонації, ансамблю, краси звучання), - ознака високого виконавського рівня хорового колективу [4, с. 88]. 
Не можемо не звернути увагу й на таку особливість хорового музикування, як поєднання в ньому слова і музики. Урівноважуючи словесну й музичну складові хорової фрази, особливу увагу доцільно звертати на розвиток та вдосконалення чітких дикційних навичок, спрямованих передусім на достатньо зрозуміле донесення до слухача літературного тексту твору. Означена літературно-поетична виразність у співі значною мірою залежить від рухливості артикуляційного апарату співака (язик, губи, зуби, нижня щелепа, альвеоли (горбики за верхніми зубами), тверде піднебіння, м'яке піднебіння маленький язичок). Зважаючи на це, хормейстер має розуміти, що робота над дикцією передбачає систематичне тренування артикуляційного апарату. Ця робота насамперед базується на чіткому усвідомленні хористом будови артикуляційного апарату та опануванні необхідних під час роботи з хором технічних вправ, наприклад, скоромовок, завдання яких - усунути проблеми виконавця, пов'язані з дикцією.

Працюючи над чіткістю вимови слова у співаній фразі, необхідно слідкувати за тим, щоб контури губ та спосіб розкриття рота при формуванні окремих звукоутворень відповідали тій чи іншій голосній, яка вимовляється. При цьому активність губ має бути настільки чіткою, щоб за їхнім рухом можна було безпомилково зрозуміти літературний текст, який промовляється співаком. Таким чином, проспівуватися у буквальному розумінні цього слова повинні лише голосні, тобто звучати якомога довше. Щодо приголосних, то вони мають лише вимовлятися. Але ця вимова має бути миттєвою, оскільки відносно довге протягування приголосних, навіть таких звучних, як $\mu, \mu$, л, може зашкодити якості звучання хору. Разом із тим, вимова приголосних повинна бути чіткою та ясною, щоб значення слова, яке будується на поєднанні приголосних і голосних звуків, можна було зрозуміти. Таке вміння хору поєднувати голосні звуки з приголосними передусім свідчить про високий рівень його вокальної майстерності.

Однак варто пам'ятати, що в роботі над дикцією недостатньо звертати увагу лише на чіткість прочитання літературного тексту. Необхідно також виокремлювати в ньому важкі для вимови слова або ж поєднання слів і прагнути вимовляти їх твердо, а в окремих випадках - скандуючи. Для досконалого «шліфування» поетичного слова та досягнення максимальних результатів у роботі над дикцією в хоровій фразі корисним буде прочитання літературно-поетичного тексту окремо від співу або ж відтворення окремих, найменших, частин музичної фрази або ж акордів, звертаючи особливу увагу на вимову поетичного тексту хорового твору [5, с. 7].

Звертаємо нашу увагу і на ще один важливий елемент хорової звучності - музичну компоненту агогіку, котра за своїм «призначенням» покликана корелювати, у процесі виконання твору, незначні відхилення від зазначеного композитором того чи того темпу, за умови збереження останнього в цілому. Таке темпове корелювання виконуваного твору, відповідно до його змісту, а саме «конструювання» динамічно-агогічної його пульсації - запорука максимальної наближеності до створення ідеального художнього образу.

Висновки. Зважаючи на викладене вище, зазначимо, що робота над елементами хорової звучності в хоровому колективі $є$ надважливою, адже результативність свідчить про становлення високої виконавської культури хору, яку необхідно не лише підтримувати, а й плідно розвивати. Ключовою умовою успіху передусім вважаємо є систематичність у роботі та вольові якості як хормейстера, так і хористів у процесі досягнення поставленої мети. Лише за таких умов мистецтво як форма суспільної свідомості, що в конкретно-чуттєвих образах відповідно до певних естетичних ідеалів набуває ознак здатності формування художнього образу спонукає людину до дії, сповненої ціннісних орієнтацій, яким би видом діяльності вона не займалася.

Подальші наші дослідження плануємо спрямувати на розгляд проблематики, пов'язаної iз впливом елементів хорової звучності на створення художньої образності в національному хоровому виконавстві та найрізноманітніших аспектів прояву цих елементів у системі координат новітнього музичного мислення.

\section{СПИСОК ВИКОРИСТАНОЇ ЛІТЕРАТУРИ}

1. Батовська О. М. Проблема строю в сучасній хоровій музиці а cappella / О. М. Батовська // Міжнародний вісник: Культурологія. Філологія. Музикознавство. - Київ : Міленіум, 2016. - № 2. C. $142-146$.

2. Білявський Е. Засвоєння сучасної музичної мови в хорі / Е. Білявський. - Київ : Музична Україна, 1984. -40 c.

3. Данилишина С. В. Особенности работы над строем в хоровых произведениях. Наука. Искусство. Культура / С. В. Данилишина, А. А. Тишина. Белград, 2017. - Вып. 4 (16). - С. 157-161.

4. Ковальська-Фрайт О. Синергія музики й слова у працях українських музикознавців Галичини першої третини XX століття / О. Ковальська-Фрайт // Вісник Львівського університету. - 2013. - Вип. 13.С. 3-15. - (Серія «Мистецтво»).

5. Коса I. А. Опанування техніки співацького дихання / I. A. Kоса. URL: https://knowledge.allbest.ru/ music/3c0b65625a2bc69a5d53a88521216d36_0.html (дата звернення: 05.01.2020).

6. Сенченко Л. І. Українська сучасна хорова література : навч. посібник для студентів вищих та середніх навч. закл. мист-ва / Л. І. Сенченко. - Рівне : РДГУ, 2002. - 80 с.

7. Смирнова Т. А. Хорознавство (історія, теорія, методика): навч. посіб. Вид. 3-є, доповн. - Харків : ХНПУ, 2018. - 212 c.

8. Чесноков П. Г. Хор и управление им / П. Г. Чесноков. - Изд 3-е. - М., 1961. - 240 с.

9. Ковальська-Фрайт О. Синергія музики й слова у працях українських музикознавців Галичини першої третини XX століття / О. Ковальська-Фрайт // Вісник Львівського університету. - 2013. - Вип. 13.С. 3-15. - (Серія «Мистецтво»).

Дата надходження до редакиї: 17.02.2020 p. 